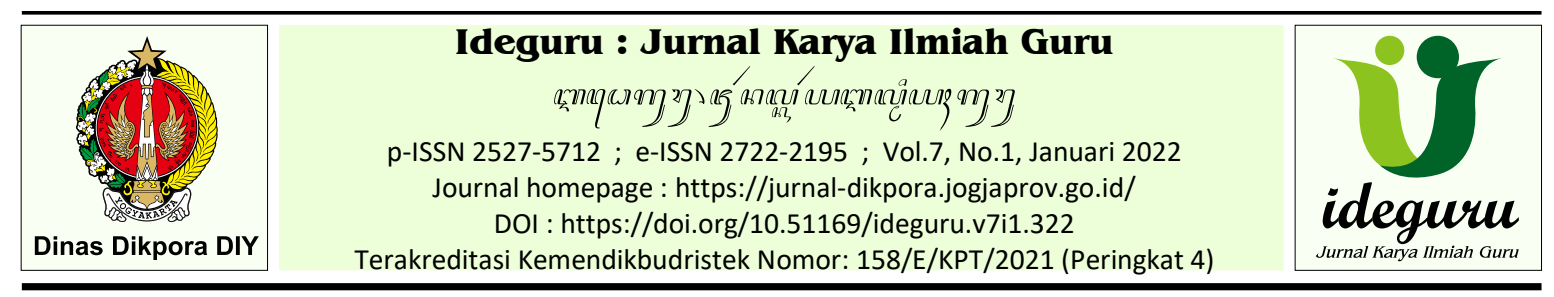

Artikel Penelitian - Naskah dikirim: 17/11/2021 - Selesai revisi: 29/11/2021 - Disetujui: 01/12/2021 - Diterbitkan: 01/01/2022

\title{
Peningkatan Keaktifan Siswa dan Hasil Belajar FPB dan KPK melalui Pembelajaran Matematika Realistik
}

\author{
Sri Hartana \\ SD Negeri Ngentakrejo, Lendah, Kulon Progo, Daerah Istimewa Yogyakarta, Indonesia \\ hartanasri465@gmail.com
}

\begin{abstract}
Abstrak: Target capaian penelitian ini untuk menjadikan siswa lebih aktif dan hasil belajar FPB dan KPK menjadi lebih baik dengan memberikan pembelajaran matematika realistik kepada siswa kelas IV SDN Ngentakrejo Kulon Progo tahun 2021 dan mendeskripsikan penerapan langkah-langkahnya. Siklus yang dirancang penelitian ini dilakukan dalam dua putaran yang dikemas menjadi lima pertemuan. Setiap pertemuan dilaksanakan dengan mengadopsi pada skema Kemmis \& Mc. Taggart yang memuat empat langkah dalam setiap putaran siklus. Penelitian ini menggunakan 26 siswa sebagai subjek yang dikenai tindakan. Data yang terkumpul melalui instrumen penelitian kemudian dianalisis untuk menghitung persentase keaktifan siswa dan seberapa banyak siswa yang tuntas belajar. Penerapan langkah-langkah pembelajaran matematika realistik yang dilakukan dengan pemberian masalah kontekstual, penggunaan alat bantu pembelajaran, diskusi kelompok, diskusi kelas, membandingkan hasil diskusi, dan menarik kesimpulan terbukti dapat membuat keaktifan siswa dan hasil belajarnya menjadi lebih baik. Persentase keaktifan siswa tampak meningkat dalam siklus I pada tiga pertemuan berturut-turut sebesar $83,46 \%, 84,23 \%$, dan $85 \%$. Siklus II pada dua pertemuan berturut-turut, persentase keaktifan siswa sebesar $85,77 \%$ dan $88,08 \%$. Sedangkan, persentase siswa tuntas belajar dalam siklus I pada tiga pertemuan berturut-turut sebesar 53,85\%, 57,69\%, dan $65,39 \%$. Siklus II pada dua pertemuan berturut-turut, persentase siswa tuntas belajar sebesar $76,92 \%$ dan $84,62 \%$.
\end{abstract}

Kata kunci: keaktifan; hasil belajar; FPB dan KPK; pembelajaran matematika realistik.

\section{Increasing Student Activity and Learning Outcomes FPB and KPK through Realistic Mathematics Learning}

\begin{abstract}
The target of this research is to make students more active and the learning outcomes of FPB and KPK to be better by providing realistic mathematics learning to fourth grade students of SDN Ngentakrejo Kulon Progo in 2021 and describing the implementation of the steps. The cycle designed for this research was carried out in two rounds which were packaged into five meetings. Each meeting was carried out by adopting the Kemmis \& Mc scheme. Taggart which contains four steps in each round of the cycle. This study uses 26 students as subjects who are subject to action. The data collected through the research instrument was then analyzed to calculate the percentage of student activity and how many students had completed learning. The application of realistic mathematics learning steps carried out by providing contextual problems, using learning aids, group discussions, class discussions, comparing discussion results, and drawing conclusions proved to be able to make student activity and learning outcomes better. The percentage of student activity seemed to increase in the first cycle at three consecutive meetings by $83.46 \%, 84.23 \%$, and $85 \%$. Cycle II in two consecutive meetings, the percentage of student activity was $85.77 \%$ and $88.08 \%$. Meanwhile, the percentage of students who finished studying in the first cycle at three consecutive meetings was 53.85\%, 57.69\%, and 65.39\%. In the second cycle in two consecutive meetings, the percentage of students who finished learning was $76.92 \%$ and $84.62 \%$.
\end{abstract}

Keywords: activity; learning outcomes; FPB and KPK; realistic mathematics learning.

\section{Pendahuluan}

Pendidikan memegang peranan penting bagi tercapainya kemajuan hidup suatu bangsa. Kualitas sumber daya manusia juga dapat ditingkatkan melalui jalur pendidikan. Sebagai salah satu disiplin ilmu yang sangat urgen dalam kehidupan, matematika senantiasa diajarkan secara kontinyu dalam semua gradasi pendidikan sejak tingkat dasar, menengah hingga jenjang paling tinggi. 
Riedesel (dalam Catur Supatmono, 2009: 7) menyatakan matematika bukan sekedar ilmu berhitung tetapi, lebih dari itu matematika menjadi ilmu yang terus berkembang sebagai alat berpikir sehingga memberikan manfaat pada semua orang. Manfaat yang dapat dipetik dari ilmu matematika sudah dirasakan manusia sejak zaman dahulu hingga masa depan, terutama dalam bidang hitung-menghitung dan pemecahan persoalan yang terjadi pada kehidupan masyarakat. Tak mengherankan jika mempelajari matematika acapkali dianggap sebagai sesuatu yang cukup prestisius dan memiliki bargaining position dalam ranah kehidupan.

Matematika memang menjadi disiplin ilmu yang acapkali diaplikasikan dalam kehidupan masyarakat, namun fakta yang terjadi pada siswa kelas IV SDN Ngentakrejo tahun 2021 menunjukkan indikasi bahwa matematika oleh sebagian siswa masih diasumsikan sebagai pelajaran yang kurang menarik karena sulit dipahami. Beberapa siswa tampak kurang aktif ketika diberikan pelajaran matematika oleh guru. Erlinda (dalam Alwi, 2021: 213-214) menyatakan adanya korelasi antara keaktifan siswa dengan pembelajaran efektif yakni ketika siswa aktif memberikan andil yang besar selama mengikuti proses pembelajaran maka siswa akan memperoleh makna yang positif dalam pembelajaran. Keaktifan siswa yang belum optimal telah berakibat pada konsep matematika menjadi sulit dikuasai sehingga siswa merasa tidak mampu memahaminya, terutama untuk pokok bahasan tentang FPB dan KPK. Tatik Farida (2009: 32-35) mengungkapkan FPB adalah bilangan terbesar yang diadopsi dengan cara memfaktorkan dari dua buah bilangan atau lebih. Sedangkan KPK adalah sebuah bilangan yang nilainya paling kecil dan bilangan tersebut dapat terbagi dari dua buah bilangan atau lebih dengan tanpa meninggalkan sisa (Himawati, 2011: 8).

Kedua materi tersebut menuntut penguasaan berbagai konsep matematika dan konsep inilah yang belum dikuasai siswa. Materi tersebut dapat dikuasai dengan baik apabila terlebih dahulu siswa sudah terampil melakukan pembagian, perkalian, dan bilangan pangkat. Suatu hal yang mudah dimaklumi, apabila nilai yang didapat siswa khususnya pada pokok bahasan FPB dan KPK masih minimalis karena rendahnya penguasaan konsep matematika oleh siswa. Apabila perolehan nilai siswa masih minimalis maka dapat dinyatakan bahwa hasil belajar siswa pasti kurang memuaskan. Hapsara (2020: 10) memberikan pengertian bahwa hasil belajar merupakan hasil yang sudah didapat siswa dengan cara menjalani evaluasi yang diberikan guru melalui sebuah aktivitas yang disebut proses belajar mengajar. Hamalik (dalam Hapsara, 2020: 10-11) mendeskripsikan bahwa hasil belajar tersebut akan tercermin dengan munculnya tingkah laku yang berbeda dengan sebelumnya di mana tingkah laku tersebut dapat diukur adanya perubahan pada aspek pengetahuan dan keterampilan. Perubahan tingkah laku yang dimaksud dapat disimak dari sikap seseorang yang semula tidak tahu menjadi tahu, dari yang tidak terampil akhirnya dapat menjadi terampil, dan sebagainya. Hasil observasi memperlihatkan, masih banyak siswa kelas IV SDN Ngentakrejo Kulon Progo tahun 2021 yang tidak berhasil mencapai target tuntas belajar. Patokan KKM sebesar 72,00 hanya dicapai 10 siswa $(38,46 \%)$ dari total 26 siswa sehingga dapat dikategorikan kurang. Tabel 1 berikut memperlihatkan banyaknya siswa yang sudah tuntas belajar dalam tahap prasiklus (sebelum diberikan tindakan).

Tabel 1. Banyaknya Siswa Tuntas Belajar Prasiklus

\begin{tabular}{ccccc}
\hline Tahun & Kelas & $\begin{array}{c}\text { Siswa } \\
\text { Tuntas } \\
\text { Belajar }\end{array}$ & $\begin{array}{c}\text { Persen } \\
\text { tase } \\
(\%)\end{array}$ & $\begin{array}{c}\text { Kate- } \\
\text { gori }\end{array}$ \\
\hline $\begin{array}{c}2021 / \\
2022\end{array}$ & IV & 10 & 38,46 & Kurang \\
\hline
\end{tabular}

Perilaku siswa yang belum menunjukkan adanya keaktifan yang baik serta nilai siswa yang tercermin melalui persentase banyaknya siswa tuntas belajar yang masih di bawah angka memuaskan tersebut harus diberikan tindakan perbaikan agar dapat menjadi lebih baik. Pembelajaran matematika realistik menjadi sebuah altternatif yang dipilih untuk mengupayakan agar keaktifan siswa dan hasil belajar dapat terdongkrak naik. Dolk (dalam Erna Yayuk, 2019: 86) menyatakan pembelajaran matematika dapat diberikan dengan mengemukakan persoalan keseharian yang harus dipecahkan dengan matematika. Pembelajaran matematika realistik sesuai teori konstruktivistik memang dilandasi dengan pengaplikasian matematika untuk memecahkan persoalan keseharian yang lazim dialami manusia.

Guru dapat memberikan pelajaran matematika dalam konteks persoalan keseharian yang pernah dialami atau diketahui oleh siswa dengan harapan dapat mempermudah penanaman konsep yang bermuara pada terdongkraknya hasil belajar. 
Alur berpikir tersebut membuat ketertarikan penulis untuk meneliti lebih jauh dan memfokuskan dalam pokok bahasan FPB dan KPK yang diterapkan dengan memberikan alternatif solusi berupa pembelajaran matematika realistik. Penulis kemudian mengonstruksi penelitian dengan tajuk "Upaya Peningkatan Keaktifan Siswa dan Hasil Belajar FPB dan KPK Melalui Pembelajaran Matematika Realistik pada Siswa Kelas IV Semester 1 SDN Ngentakrejo Tahun Pelajaran 2021/2022."

Hasil identifikasi yang dilakukan terhadap persoalan yang dialami siswa kelas IV SDN Ngentkarejo tahun 2021 membuat penulis merumuskan penelitian ini dalam tiga fokus kajian yaitu: 1) Apakah langkah-langkah pembelajaran matematika realistik dapat menjadikan siswa kelas IV SDN Ngentakrejo tahun 2021 menjadi lebih aktif? 2) Apakah langkah-langkah pembelajaran matematika realistik dapat menjadikan siswa kelas IV SDN Ngentakrejo tahun 2021 memiliki hasil belajar yang lebih baik pada pokok bahasan FPB dan KPK? 3) Bagaimana mengaplikasikan langkahlangkah pembelajaran matematika realistik sehingga dapat menjadikan keaktifan siswa dan hasil belajar FPB dan KPK kelas IV SDN Ngentakrejo tahun 2021 lebih baik?

Penelitian ini memiliki tiga sasaran utama yang hendak diraih yaitu: 1) Keaktifan siswa kelas IV SDN Ngentakrejo tahun 2021 dapat meningkat setelah diberi tindakan berupa pembelajaran matematika realistik. 2) Banyaknya siswa kelas IV SDN Ngentakrejo tahun 2021 yang tuntas belajar FPB dan KPK dapat menaik setelah diberi tindakan berupa pembelajaran matematika realistik. 3) Penerapan langkah-langkah pembelajaran matematika realistik dideskripsikan agar perilaku siswa lebih aktif dan banyaknya siswa kelas IV SDN Ngentakrejo tahun 2021 yang tuntas belajar FPB dan KPK dapat bertambah.

Hasil yang diharapkan setelah dilakukan penelitian diantaranya: 1) Keaktifan siswa dan banyaknya siswa yang tuntas belajar FPB dan KPK menjadi lebih baik, siswa memperoleh makna mendalam melalui pembelajaran yang diberikan, dan siswa mendapat pengalaman bekerjasama dalam kelompok. 2) Guru dapat menciptakan proses belajar mengajar yang memfokuskan pada kepentingan siswa, mendapat pengalaman dalam menerapkan pembelajaran matematika realistik, dan guru memiliki rasa percaya diri dalam meningkatkan hasil belajar siswa. 3) Sekolah dapat memperoleh peningkatan kualitas pembelajaran serta mendapatkan referensi untuk menyusun riset yang menghasilkan publikasi ilmiah.

\section{Metode Penelitian}

Tempat dilakukannya penelitian ini mengambil lokasi di SDN Ngentakrejo. Sekolah ini terletak di Dusun Temben, Kelurahan Ngentakrejo, Kapanewon Lendah, Kabupaten Kulon Progo. Durasi waktu dalam melakukan penelitian yaitu selama empat bulan mulai Agustus hingga November 2021. Penelitian ini mengadopsi 26 siswa kelas IV SDN Ngentakrejo tahun 2021 sebagai subjek penelitian. Proses pembelajaran dilaksanakan secara luring (luar jaringan) dengan memprioritaskan keselamatan warga sekolah sebagai prioritas utama.

Hal ini dilakukan berdasarkan rekomendasi pemerintah kabupaten dalam hal ini Dinas Pendidikan Pemuda dan Olahraga Kabupaten Kulon Progo dengan surat Nomor 421/2514 tanggal 12 Oktober 2021 tentang Rekomendasi/Izin melaksanakan Pembelajaran Tatap Muka Terbatas (PTMT) untuk SDN Ngentakrejo mulai tanggal 18 Oktober 2021. Pembelajaran diaplikasikan dengan memilah siswa menjadi dua shift masing-masing 13 siswa setiap shift sesuai jadwal yang berlaku di sekolah. Sebelum masuk areal sekolah siswa dicek suhu badannya dengan thermogun dan dicatat rekam jejak perjalanan jauh yang dilakukan. Selama berada di areal sekolah, siswa diingatkan agar dapat menjaga kesehatan diri dan orang lain dengan seringkali mencuci kedua tangan, mengatur jarak (tidak berdekatan), dan tidak melakukan pinjam-meminjam alat pelajaran.

Penelitian tindakan kelas dilakukan secara berkolaborasi dengan kepala sekolah ini berbentuk siklus yang dikemas melalui empat tahapan utama pada setiap pertemuan. Zainal Aqib (dalam Sri Hartana, 2013: 45-46) menyatakan, tahapan yang dilalui dalam melakukan penelitian di kelas meliputi tahap merencanakan, melaksanakan, mengamati, dan merefleksi. Waktu yang digunakan kolaborator untuk menilai guru dan siswa bersamaan dengan waktu yang digunakan kegiatan guru di kelas. Begitu pula tempatnya juga sama dengan tempat yang digunakan guru melakukan pembelajaran. Kolaborator mengamati guru dan siswa ketika sedang menjalankan proses pembelajaran. Seluruh tahapan yang dilalui dalam skema penelitian ini mengadopsi pada skema penelitian yang dikemukakan Kemmis \& Mc. Taggart.

Pada siklus I pertemuan pertama, guru bersama kolaborator menyusun skenario berupa rancangan tindakan yang akan dilaksanakan dengan mempersiapkan RPP, alat bantu 
pembelajaran, lembar observasi, dan soal tes. Selanjutnya, skenario tersebut dilaksanakan oleh guru dalam pemberian tindakan pada proses pembelajaran di kelas. Peran kolaborator adalah mengamati pelaksanaan pembelajaran dan hasil yang dicapai dalam pembelajaran. Refleksi dalam format diskusi dilakukan oleh guru bersama kolaborator setelah guru menyelesaikan proses pembelajaran. Guru dan kolaborator mendiskusikan hasil yang dicapai dan masalah yang muncul akibat dari pemberian tindakan tersebut. Guru dan kolaborator melaksanakan siklus I pertemuan kedua dan ketiga seperti yang dilakukan pada pertemuan pertama yakni melakukan keempat tahapan tersebut. Sedangkan, pada siklus II pertemuan pertama dan kedua guru bersama dengan kolaborator juga melakukan keempat tahapan tersebut.

Data penelitian dihimpun melalui piranti penelitian berupa lembar observasi dan soal tes. Observasi yang dilakukan kolaborator dengan cara berada di dalam kelas dan melakukan pengamatan jalannya proses pembelajaran serta hasil yang didapat dari proses pembelajaran. Observasi dilakukan kolaborator pada setiap pertemuan yang dilakukan guru. Objek yang diamati adalah perlakuan guru dan tingkat keaktifan siswa selama pembelajaran dilakukan. Instrumen untuk mengamati guru digunakan untuk melihat ketercapaian 16 kegiatan yang dijalankan guru dalam memberikan tindakan kepada siswa.

Sedangkan, instrumen pengamatan siswa digunakan untuk melihat terhadap keaktifan siswa yang terdiri tiga komponen yakni aktif, kerjasama, dan teliti yang dijabarkan dalam 12 indikator. Arikunto (dalam Wawan Rismawan, 2013: 110) membagi pengukuran skala pengetahuan dalam tiga kategori yaitu: 1) Kategori baik, jika terdapat $76 \%-100 \%$ poin yang berhasil diperoleh seseorang, 2) Kategori cukup, jika terdapat $56 \%-75 \%$, poin yang berhasil diperoleh seseorang dan 3) Kategori kurang, jika terdapat $<56 \%$. poin yang berhasil diperoleh seseorang. Pedoman inilah yang digunakan untuk menyatakan kategori dari hasil yang berhasil dihimpun dari pengambilan data penelitian ini.
Instrumen berupa soal tes yang diaplikasikan penelitian ini termasuk jenis soal uraian yang memuat pokok bahasan FPB dan KPK yang harus dikerjakan siswa dalam setiap pertemuan dalam pembelajaran. Hasil tes siswa dibandingkan dengan KKM sekolah yakni 72,00. Jika nilai yang diperoleh siswa sama atau lebih tinggi dari KKM, maka siswa dianggap telah tuntas belajar. Penelitian ini dianggap berhasil jika telah mencakup tiga kriteria berikut: 1) Keaktifan siswa memperoleh nilai paling sedikit $80 \%, 2)$ Siswa yang tuntas belajar mencapai paling sedikit $80 \%$ dan 3) Langkah-langkah pembelajaran matematika realistik sudah diaplikasikan pada pokok bahasan FPB dan KPK siswa kelas IV SDN Ngentakrejo tahun 2021.

Data hasil penelitian kemudian dianalisis secara deskriptif kualitatif untuk menentukan besarnya persentase siswa yang aktif dan yang telah tuntas belajar setelah diberikan tindakan oleh guru. Data hasil penelitian dianalisis melalui prosedur berikut: 1) Menghitung tingkat keaktifan siswa yaitu perbandingan perolehan skor keaktifan siswa dengan jumlah skor maksimal keaktifan siswa dan 2) Menghitung banyaknya siswa yang sudah tuntas belajar yaitu membandingkan banyaknya siswa yang sudah tuntas belajar dengan jumlah keseluruhan siswa.

\section{Hasil dan Pembahasan}

Hasil observasi atas perlakuan yang diberikan oleh guru pada siklus I dan II yang dilakukan kolaborator menunjukkan besarnya kegiatan yang telah dilakukan guru. Tabel 2 berikut dapat memperlihatkan hasil yang dicapai dari kegiatan guru yang berhasil direkap dari siklus I dan II pada setiap pertemuan.

Tabel 2 memperlihatkan kegiatan guru siklus I pertemuan pertama sebanyak 12 atau $75 \%$ dengan kategori cukup. Kegiatan guru pertemuan kedua sebanyak 14 atau $87,5 \%$ dengan predikat baik dan pertemuan ketiga sebanyak 15 atau 93,75\% dengan kategori baik. Kegiatan guru siklus II pertemuan pertama sebanyak 16 atau $100 \%$ dengan kategori baik dan pertemuan kedua sebanyak 16 atau $100 \%$ dengan kategori baik.

Tabel 2. Rekapitulasi Kegiatan Guru Siklus I dan II

\begin{tabular}{cccc}
\hline Siklus/Pertemuan & Kegiatan & Persentase (\%) & Kategori \\
\hline I/1 & 12 & 75 & Cukup \\
I/2 & 14 & 87,5 & Baik \\
I/3 & 15 & 93,75 & Baik \\
II/1 & 16 & 100 & Baik \\
II/2 & 16 & 100 & Baik \\
\hline
\end{tabular}


Tabel 3. Rekapitulasi Keaktifan Siswa Siklus I dan II

\begin{tabular}{cccc}
\hline Siklus/Pertemuan & Skor Keaktifan & Persentase (\%) & Kategori \\
\hline I/1 & 217 & 83,46 & Baik \\
I/2 & 219 & 84,23 & Baik \\
I/3 & 221 & 85 & Baik \\
II/1 & 223 & 85,77 & Baik \\
II/2 & 229 & 88,08 & Baik \\
\hline
\end{tabular}

Guru belum dapat melaksanakan seluruh kegiatan guru yang dikemas dalam RPP pada siklus I sehingga hasil capaiannya belum optimal. Guru mengaku lupa melakukan beberapa kegiatan sesuai skenario yang telah dirancang dalam RPP diantaranya melakukan apersepsi, menyampaikan tujuan pembelajaran, memberikan motivasi dengan pertanyaan penuntun, membandingkan hasil diskusi, dan melakukan refleksi.

Kegiatan guru menjadi lebih baik setelah guru dan kolaborator mendiskusikan proses dan hasil yang diperoleh pada siklus I. Hasil refleksi memberikan saran agar guru memperbaiki proses pembelajaran yang dilakukan dengan melaksanakan sebanyak 16 atau seluruh kegiatan guru yang sudah dituangkan dalam RPP. Perbaikan tindakan ini dimaksudkan supaya pada siklus berikutnya memperoleh proses dan hasil yang lebih baik lagi.

Hasil pengamatan kolaborator pada keaktifan siswa siklus I dan II memperlihatkan skor siswa yang aktif semakin baik. Data pada tabel 3 dapat menunjukkan hasil yang dicapai dari keaktifan siswa pada siklus I dan II pada setiap pertemuan.

Tabel 3 memperlihatkan skor keaktifan siswa siklus I pertemuan pertama sebanyak 217 atau $83,46 \%$ dengan kategori baik. Skor keaktifan siswa pertemuan kedua sebanyak 219 atau $84,23 \%$ memperoleh predikat baik dan pertemuan ketiga sebanyak 221 atau $85 \%$ dengan kategori baik. Keaktifan siswa siklus II pertemuan pertama sebanyak 223 atau $85,77 \%$ dengan kategori baik dan pertemuan kedua sebanyak 229 atau 88,08\% dengan predikat baik. Capaian angka keaktifan siswa tersebut memperkuat asumsi awal bahwa pembelajaran matematika realistik yang diterapkan dapat menghasilkan tingkat keaktifan siswa semakin tinggi.

Pada kondisi siklus I, keaktifan siswa memang tampak masih belum maksimal ketika sedang menjalani proses pembelajaran. Beberapa siswa masih belum aktif terutama ketika melaksanakan diskusi kelompok. Ada siswa yang memahami kerja kelompok berarti tidak perlu berpikir dan tinggal mencontoh hasil kerja temannya. Beberapa siswa laki-laki masih tampak malu-malu untuk berkelompok dengan siswa perempuan. Siswa juga masih ada yang tidak teliti dalam mengerjakan soal.

Melihat pembelajaran yang masih belum optimal maka guru dan kolaborator melakukan diskusi dan menghasilkan rekomendasi bagi guru supaya mengupayakan tindakan perbaikan ketika melaksanakan siklus II. Siswa yang tidak memfokuskan perhatiannya terhadap pelajaran ditegur guru agar lebih fokus. Siswa yang kurang teliti diberikan saran agar mengecek kembali hasil kerjanya. Tujuan yang diharapkan dari upaya perbaikan proses pembelajaran ini supaya hasil yang diraih siswa dapat berubah menjadi lebih maksimal.

Penerapan langkah-langkah pembelajaran matematika realistik pada siklus I telah menyebabkan keaktifan siswa menjadi lebih baik. Kuiper dan Knuver (dalam Syafri Ahmad, dkk., 2020: 41-42) menyatakan pembelajaran matematika realistik memiliki nilai keunggulan tersendiri yaitu lebih menarik, relevan, dan mampu memberikan makna pada pembelajaran yang berlangsung. Tingkat keaktifan siswa selama proses pembelajaran dilakukan guru menjadi semakin mantap sehingga ketika mengerjakan soal evaluasi juga semakin lebih baik. Dampak positif yang muncul dari tindakan yang diberikan guru yaitu jumlah siswa yang tuntas belajar semakin banyak.

Hasil observasi kolaborator pada hasil pekerjaan yang diperoleh berupa nilai tes siswa pada siklus I dan II menunjukkan adanya kenaikan. Hal itu tampak pada persentase siswa yang dianggap tuntas belajar atau mendapat nilai paling sedikit sama dengan KKM, yakni 72,00. Pada tabel 4 dapat menunjukkan ketuntasan belajar siswa siklus I dan II yang telah berhasil meningkat pada setiap pertemuan.

Tabel 4 memperlihatkan bahwa siswa yang dianggap tuntas belajar pada siklus I pertemuan pertama sejumlah 14 atau $53,85 \%$ dengan kategori cukup. Jumlah siswa yang dianggap tuntas belajar pada pertemuan kedua yaitu 15 atau $57,69 \%$ dengan kategori cukup dan pertemuan ketiga sebanyak 17 atau $65,39 \%$ dengan kategori cukup. 
Tabel 4. Rekapitulasi Siswa Tuntas Belajar Siklus I dan II

\begin{tabular}{cccc}
\hline Siklus/Pertemuan & Tuntas Belajar & Persentase (\%) & Kategori \\
\hline I/1 & 14 & 53,85 & Cukup \\
I/2 & 15 & 57,69 & Cukup \\
I/3 & 17 & 65,39 & Cukup \\
II/1 & 20 & 76,92 & Baik \\
II/2 & 22 & 84,62 & Baik \\
\hline
\end{tabular}

Sedangkan, jumlah siswa yang dianggap tuntas belajar pada siklus II pertemuan pertama yaitu 20 atau 76,92\% dengan kategori baik dan pertemuan kedua sebanyak 22 atau $84,62 \%$ dengan kategori baik. Hasil capaian banyaknya siswa yang tuntas belajar pada kedua siklus tersebut membuktikan bahwa pembelajaran matematika realistik dapat menghasilkan output yang menggembirakan, khususnya pada nilai tes FPB dan KPK siswa.

Ketika proses pengerjaan soal tes diamati, kemampuan mengerjakan soal tes siswa pada siklus I terlihat masih belum optimal. Beberapa siswa tampak kurang memahami konsep yang diberikan guru sehingga merasa kesulitan dalam mengerjakan soal. Beberapa siswa juga tampak kurang teliti dalam mengerjakan tes sehingga masih salah dalam menjawab soal tes. Perkembangan selanjutnya, siswa nampak menunjukkan kemampuan mengerjakan soal tes pada siklus II yaitu setelah guru melakukan tindakan perbaikan berdasarkan hasil diskusi bersama kolaborator. Hasil refleksi memberikan saran supaya guru meningkatkan pemberian motivasi agar siswa lebih teliti dan lebih mudah memahami konsep. Selain itu, alat bantu pembelajaran juga perlu diganti yang lebih realistis sehingga semakin memudahkan siswa memahami konsep yang diberikan. Tindakan ini dilakukan dengan target supaya jumlah siswa yang tuntas belajar menjadi lebih banyak.

Setelah guru melakukan perbaikan terhadap tindakan yang diberikan kepada siswa, hasil belajar siswa memang mengalami peningkatan sehingga jumlah siswa yang tuntas belajar semakin naik. Marpaung (dalam Syafri Ahmad dkk, 2020: 41-43) menyatakan bahwa pembelajaran matematika realistik memiliki banyak keunggulan dan salah satunya yaitu berpusat pada siswa sehingga memunculkan keberanian dalam diri siswa untuk menyelesaikan masalah. Pemberian motivasi berupa pertanyaan penuntun dapat memudahkan siswa memahami konsep. Siswa juga lebih teliti dalam mengerjakan soal tes setelah diberikan motivasi oleh guru. Akhirnya, secara keseluruhan kriteria yang ditetapkan dalam penelitian ini sudah dapat terpenuhi.

\section{Simpulan dan Saran}

Hasil yang dicapai dari pelaksanaan penelitian ini dapat ditarik simpulan bahwa penerapan langkah-langkah pembelajaran matematika realistik dapat membuat keaktifan siswa menjadi semakin naik. Selain itu, hasil capaian nilai siswa pada pokok bahasan FPB dan KPK kelas IV SDN Ngentakrejo Kulon Progo tahun 2021 juga semakin baik.

Keaktifan siswa terlihat semakin meningkat dalam siklus I pada tiga pertemuan berturut-turut sebesar 83,46\%, 84,23\%, dan $85 \%$ serta dalam siklus II pada dua pertemuan berturut-turut sebesar 85,77\% dan 88,08\%. Sedangkan, persentase siswa yang tuntas belajar juga tampak semakin menaik dalam siklus I pada tiga pertemuan berturut-turut sebesar 53,85\%, $57,69 \%$, dan $65,39 \%$ serta dalam siklus II pada dua pertemuan berturut-turut sebesar $76,92 \%$ dan $84,62 \%$.

Penerapan langkah-langkah pembelajaran matematika realistik dilakukan dengan pemberian masalah kontekstual terkait materi FPB dan KPK yang dipahami dengan mempraktikkan alat bantu pembelajaran. Siswa tampak aktif ketika mempraktikkan alat bantu pembelajaran berupa sedotan minuman maupun papan kelipatan bilangan sehingga meningkatkan pemahaman siswa terhadap beberapa konsep matematika. Kerjasama antarsiswa tumbuh saat mengikuti diskusi kelompok dan ketelitian siswa semakin baik ketika membandingkan hasil diskusi. Penyelesaian masalah kontekstual yang dilakukan melalui kegiatan dalam menarik kesimpulan yang dilakukan antara guru dan siswa.

Simpulan yang diperoleh dalam penelitian ini memberikan saran terhadap guru yang menerapkan pembelajaran matematika realistik yaitu: 1) Persiapan mental, emosional, dan penguasaan materi sangat diperlukan agar proses pembelajaran berjalan sesuai skenario dan penguasaan kelas juga dapat terwujud. 2) Penggunaan alat bantu pembelajaran diupayakan lebih menarik agar siswa lebih mudah memahami konsep yang hendak ditanamkan. 


\section{Daftar Pustaka}

Ahmad, S., dkk. (2020). Pendekatan Realistik dan Teori Van Hiele. Yogyakarta: Penerbit Deepublish.

https://www.google.co.id/books/edition/P endekatan_Realistik_Dan_Teori_Van_Hiele /S-

gaEAAAQBAJ?hl $=\mathrm{id} \& \mathrm{gbpv}=1 \& \mathrm{dq}=$ realisti $\mathrm{k}+$ dee + publish\&printsec $=$ frontcover

Diakses pada hari Senin tanggal 22 November 2021 pukul 09.27 WIB.

Alwi, M. (2021) Upaya Peningkatan Aktivitas dan Hasil Belajar Kimia Melalui Model Pembelajaran Kooperatif Siswa SMAN 9 Kota Jambi Tahun Pelajaran 2018/2019. LEARNING: Jurnal Inovasi Penelitian Pendidikan dan Pembelajaran, 1(2). https://www.jurnalp4i.com/index.php/lear ning/article/view/591

Farida, T. (2009). Buku Pintar Matematika untuk SD. Solo: Bringin 55.

Hapsara, AS. (2020). Peningkatan Partisipasi dan Hasil Belajar Daring Sosiologi melalui Pendekatan Problem Posing Berbasis Infografis. Ideguru: Jurnal Karya Ilmiah Guru, 5(2), 9-19. https://doi.org/10.51169/ideguru.v5i2.17 0

Hartana, S. (2013). Peningkatan Keterampilan Menulis Karangan Deskripsi dengan Metode Field Trip di Kelas IV SD Negeri Gegulu Kulon Progo. Skripsi. Fakultas Ilmu Pendidikan Univeristas Negeri Yogyakarta, Yogyakarta. http://eprints.uny.ac.id/15019/1/SKRIPSI
\%20SRI\%20HARTANA\%2010108247055.p df Diakses pada hari Minggu tanggal 21 November 2021 pukul 22.11 WIB.

Himawati, E. (2011). Menghitung Faktor Persekutuan Terbesar (FPB) dan Kelipatan Persekutuan Terkecil (KPK). Jakarta: Be Champion.

Rismawan, W. (2013). Gambaran Pengetahuan dan Sikap Keluarga dalam Perawatan Pasien Gangguan Jiwa dengan Masalah Keperawatan: Isolasi Sosial di RSUD Kota Tasikmalaya. Jurnal Kesehatan Bakti Tunas Husada, 9(1). https://ejurnal.stikesbth.ac.id/index.php/P3M_JKBTH/article/d ownload/102/102.

Supatmono, C. (2009). Matematika Asyik; Asyik Belajarnya Asyik Mengajarnya. Jakarta: Grasindo.

https://www.google.co.id/books/edition/ Matematika_Asyik/zw5DFCbBPBgC?hl=id $\& \mathrm{gbpv}=1 \& \overline{\mathrm{d} q}=$ catur + supatmono $\& \mathrm{pg}=\mathrm{PR} 2$ \&printsec $=$ frontcover Diakses pada hari Senin tanggal 22 November 2021 pukul 09.30 WIB.

Yayuk, E. (2019). Pembelajaran Matematika SD. Malang: Universitas Muhammadiyah Malang.

https://www.google.co.id/books/edition/P EMBELAJARAN_MATEMATIKA_SEKOLAH_ DASAR/uc_oDwAAQBAJ?hl $=\mathrm{id} \& \mathrm{gbpv}=1 \bar{\varepsilon}^{-}$ $\mathrm{dq}=$ Pembelajaran + Matematika $+\mathrm{SD}+$ erna +yayuk\&printsec $=$ frontcover Diakses pada hari Senin tanggal 22 November 2021 pukul 09.35 WIB. 